International Journal of Canadian Studies

Revue internationale d'études canadiennes
INTERNATIONAL JOURNAL OF CANADIAN STUDIES

REVUE INTERNATIONALF D'ÉTUDES CANADIENNES

\title{
Engaging the Postcolonial: Terrorism, Tourism, and Literary Cosmopolitanism in the Twenty-First Century
}

\section{Srilata Ravi}

Numéro 44, 2011

URI : https://id.erudit.org/iderudit/1010089ar

DOI : https://doi.org/10.7202/1010089ar

Aller au sommaire du numéro

Éditeur(s)

Conseil international d'études canadiennes

ISSN

1180-3991 (imprimé)

1923-5291 (numérique)

Découvrir la revue

Citer cet article

Ravi, S. (2011). Engaging the Postcolonial: Terrorism, Tourism, and Literary Cosmopolitanism in the Twenty-First Century. International Journal of

Canadian Studies / Revue internationale d'études canadiennes, (44), 215-227.

https://doi.org/10.7202/1010089ar 


\section{Srilata Ravi}

\section{Engaging the Postcolonial: Terrorism, Tourism, and Literary Cosmopolitanism in the Twenty-First Century}

The May 2007 issue of Publications of the Modern Language Association (PMLA) featured an Editor's Column entitled "The End of Postcolonial Theory?" In this very timely and illuminating discussion, one of the participants asks whether postcolonial theory's failure was perhaps due to its inability to match knowledge and the world (Yaeger). A legitimate question indeed if we consider the diverse range of unresolved issues that continue to haunt postcolonial societies, like terrorism, environmental damage, and cultural untranslatability, to name only a few. In other words, is the term "postcolonial" still valid in the interpretation of contemporary societies? Notwithstanding the skepticism expressed in the title of the PMLA editorial, recent scholarly publications like the ones referred to in this essay have proven that when the "postcolonial" is creatively integrated into other paradigms like the "cosmopolitan," the "transnational," and the "global" it provides a richer and more nuanced account of contemporary society.

In 1978 Said's groundbreaking Orientalism produced a critique of Western metaphysics and exposed Eurocentric categories and imperial metanarratives. This in turn generated a series of studies that examined neglected aspects of imperial domination and subaltern subject formations. The term "postcolonial" became a critical lens to examine the complicity between knowledge and power both in the past and in the present. Centring its analyses on culture as forms of representation instead of on political economy, "postcolonial" studies examined gender, sexuality, race, social class, and other forms of identity and uncovered the colonial dimensions of diverse sites of marginality, alterity, and subalternity. Critics like Slemon adapted the field's principal parameters to read settler colony/second world cultures of Canada and Australia.

Despite the extent of its intersection with other fields and disciplines, postcolonialism's theoretical gaps have come under scrutiny (McClinctok; Shohat; Dirlik; Gikandi). Since the publication in the 1980s of the seminal works of Said, Bhabha, and Spivak, the field's fundamental understanding of colonialism as a determining marker of history, its tendency to homogenize cultures, times, and cultural formations, and its approbation of "deterministic economism" have all come under heavy criticism as pointed out by the participants in the PMLA round table discussion (Yaeger). Postcolonialism's complicity with the global politics of Euro-American academia has also been criticized (Dirlik). 
Yet numerous studies in the last twenty years (one need only look at titles and special issues of journals published by prestigious university and commercial presses across the world) have shown that the field has enormously benefitted from these criticisms, which have turned out to be expressions of a productive crisis. Postcolonialism's engagement with globalization and cultural critics' use of "postcolonial" as a paradigm to read the transnational and translational conditions of migrancy have resulted in a number of important works. As Ashcroft argues, the postcolonial, by adapting itself to vernacular debates and local academic traditions, remains a relevant project to recover the local and regional. Globalization when understood "aculturally" translates as the diffusion of capital, urbanization, industrialization, and education in a unified world with a homogenous program available to all. But as Asheroft points out, globalization is a multidirectional and a transcultural process, and it operates not necessarily hierarchically nor centrifugally but "rhizomically" (86, following Edouard Glissant). In Ashcroft's view, postcolonial transformation is the key process that engages the local with the global and illuminates the emergence of multiple/postcolonial modernities (89). Using Ashcroft's definition of a transformative paradigm of postcolonialism, I would like to focus on three key fields of enquiry that global modernities have produced, namely terrorism, tourism, and literary cosmopolitanism. These fields of enquiry are central to three recent publications-Terror and the Postcolonial (Boehmer and Morton, eds.); Postcolonial Tourism: Literature, Culture and the Environment (Carrigan); and Transnational French Studies: Postcolonialism and LittératureMonde (Hargreaves, Forsdick, and Murphy, eds.) - that have inspired this essay. Following from some of the arguments presented in these works, I will argue for the validity and relevance of the "postcolonial" a) through its association with the category of the aesthetic that provides pathways to understand terror; b) through its interdisciplinary approach to postcolonial writing that informs empirical research on tourism development; and c) through its engagement with non-Anglophone academic fields of enquiry that problematizes the notion of transnationalism and translatability. A brief concluding section will use Sean Mills' recent publication The Empire Within: Postcolonial Thought and Activism in Sixties Montreal to look at the relevance of the postcolonial paradigm in the study of Quebec politics and its potential to recuperate the ambiguities of local/global dynamics.

\section{Aesthetics of Terror and Postcoloniality}

The wave of "terrorism studies" unleashed by $9 / 11$ located the origins of terror for the most part in religious fundamentalism and its spread in the modern secular nation state. These investigations in turn have produced numerous studies on the re-evaluation of the role of religion in contemporary society. While such research has enabled productive rethinking of modernist categories like "secular" and national policies like "multiculturalism" used to manage cultural difference in global societies, it does not interrogate the history of terrorism 
itself. By falsely linking fear of terror to discourses of secularization, attention is drawn away from the more historically entrenched factors that inform the discourse. Focusing specifically on the history of colonialism, Boehmer and Morton in their introductory essay in Terror and the Postcolonial claim that previous studies have not taken into account the colonial and terroristic forms of contemporary imperialism. They give themselves the task of redefining the vocation of postcolonial studies for terror, by producing a "new history of the present" (Gopal and Lazarus, quoted in Boehmer and Morton 8). They are quick to add, however, that a postcolonial approach does not apologize for the terrorist nor deny acts of terror; rather it exposes the continuing orientalist logic of the discourse of terrorism.

Boehmer reminds us in her essay in Terror and the Postcolonial that the "postcolonial" today has two inflections: the "global, hybridizing inflection" and the "resistance" inflection (143). Kavoori in Media, Terrorism, and Theory, emphasizing the globalizing inflection of the "postcolonial," observes that the notions of diaspora (evoking deterritorialization) and hybridity (suggesting indeterminacy), which contain the central themes of power and complexity, are crucial to the issue of cultural identity and terrorism (193). If globalized postcolonial identities are not continuous but framed between "simultaneous vectors of similarity, continuity and difference" then such a paradigm cannot fix the terrorist as a category defined by his antipathy to nation state or historically as a generator of nationalist movements - the category of terrorist is therefore mobile, concludes Kavoori (194-95). He claims that the postcolonial construction of terrorist must be also be configured along other axes of domination and resistance. In other words, the category of terrorist is shaped by gender, race, sexuality, religion, and political orientations as well (194). Such a reading debunks media and "official" discourse, which remain narrowly marked by concerns of religion, masculinity, and "Arabness."

While Kavoori suggests that colonization/decolonization has transnational dimensions and that its local expressions are multiply inflected by regional and global affinities and considerations, such a "globalizing" view of terror does not closely scrutinize the continuities of the discourse of terrorism, argue Boehmer and Morton in Terror and the Postcolonial. Affirming that authoritative structures of the colony continue effectively in a post-imperial nation, they argue that in order to understand colonial forms of present-day terror one needs to "turn back to certain modes of imperial history in order to understand and explicate these apparent continuities" (7) and as such to examine terror as a dominant form through which the colonial is reiterated in a postcolonial world.

But by showing the "unchanging nature of the world" can a postcolonial reading achieve its "transformative potential?" Will not the constant recourse to the past, to illuminate and justify the present, end up reinforcing discourses of victimization? Two essays in Terror and the Postcolonial, one by Mbembe and 
the other by Young, open up the "postcolonial" to engage with the "aesthetics" of terror in answering these questions. In an interview with Christian Höller, Mbembe notes:

[T] here is no way we will overcome the neurosis of victimization if, by transforming the past into our subjective present, we root our identities in injury alone. For the past to become a principle of action in the present, we have to manage to admit the reality of loss and stop living in the past instead of integrating it in to the present as that which must sustain human dialogue. In any case, the complete restitution of the past is not only terrifying, but also a clear impossibility.

Is there a subtle critique here of postcolonialism's theoretical centring on colonial history? By focusing on State terror in the present African context, Mbembe, in his critique of the postcolony, moves away from the definition of terror as tied up with the "Orientalist logic" and also stays clear of the sensationalized link between religious fundamentalism and violence. This idea is brought home forcefully in his essay in Terror and the Postcolonial (27-54). Mbembe does not reject the history of a colonial past; he refuses to integrate it linearly to the present of the postcolony. He calls for liberation from the past without erasing it. Such a project is epistemologically impossible to explain within a straightforward linear "postcolonial" paradigm of oppression/ resistance and negotiation. Mbembe, therefore, regards the "postcolony" as an "entanglement" of temporalities, a timescape that is simultaneously in the process of being formed and of being dissolved through a movement that brings both the "being formed" and the "being dissolved" into collision (Höller).

Where Mbembe moves away from a pure politico-historical reading of power in his essay in Terror and the Postcolonial is in his examination of the intersections between aesthetics of terror and the aesthetics of recollection (of the terror). He does not examine continuity to prove neo-imperialist practices but to recognize the "sites where the phenomenon which was essentially a mixture of fear, desire and terror may have been created" (49). He points out that the colonial and the African potentate (46) in order to set up a lay cult had built an entire emotional economy, a mixture of seduction and terror that dominated the senses, where power is ubiquitous both in presence and in the realm of the tactile. Such violence, Mbembe argues, does not appeal to reason as a category of public life, but to bodily sensations. However, as a bundle of energies and brutal fantasies, and by sheer coercive repetition, these fantasies of terror end up becoming part of the "aesthetic" of everyday life: "To remember the colony, then is to meditate upon this absence and thus allow the theme of sepulcher to take its full force" (Höller). Mbembe claims that it is in these sensory (i.e., the aesthetic) "everyday life examples" that fragments of the past can be "recycled" into the possibility for transformation through realization of loss. 
Young, in the same collection, focusing on the psychic and Gothic dimensions of terror, claims that fiction is the best place to understand that terror cannot have meaning in the real since it breaks down the difference between authentic and inauthentic (307-28). It must be noted, however, that Young avoids generalizations by differentiating between First World terror (experienced by most at a remove) and terror's traumatic effects experienced on a day-to-day basis (as in Sri Lanka or in parts of Africa): terror as suspense and terror as trauma both operate within postcolonial dimensions. If, as Young claims, terror is both discourse and product of discourse, real and unreal, effect and affect, then there seems to be no way out of the fact that terror as an "aesthetic" can only reproduce terror and the fascination for terror endlessly. As Berleant (2009) points out, recognizing the aesthetic in acts of terrorism does not condone nor justify such action. Recognizing its presence in this manner helps us to understand that the theatrical forcefulness that impresses us with their image is "indissolubly bound up with their moral negativity, and identifying them as the negative sublime is to condemn them beyond all measure." What is of interest to us is that both Mbembe and Young, focusing on the e/affects of terror, its repeatedness, and its sensory force, point out that reading terror uniquely through a historical and hegemonic lens cannot be a solution. They suggest that a form of "postcolonial" and transformative resistance can be made through the aesthetic of a "radically reimagined voyage" into the ethical, psychic realm of what Young calls "post-human" (Terror and the Postcolonial 326) and what Mbembe calls memorialisation (Terror and the Postcolonial 47) or the "resurrection of the dead at the intersection of poetics and politics."

\section{Postcolonial Environments and Tourism Development}

Anthony Carrigan's Postcolonial Tourism: Literature, Culture and Environment addresses the category of the "postcolonial" within discourses of sustainability, environment, and tourism. Despite its anthropocentric focus, postcolonial studies must be credited with having engaged with the human as well as the non-human in contemporary society. Huggan and Tiffin, in Postcolonial Eco-criticism, claim that postcolonial criticism wishes to reach out across languages and cultures "to make exploitation and discrimination of all kinds, of both human and non-human, visible in the world" (16). They argue that if the wrongs of colonialism should be addressed and redressed, the category of the human in relation to the non-human has to be questioned. If humanism were to challenge the historical condition under which societies have constructed themselves hierarchically in relation to other societies, both human and non-human, then exploring the ecological connection between the two will lead to a transformative process (21). In his reading of internal migrancy and globalization in Ghosh's The High Tide, Pablo Mukherjee argues that Ghosh's text suggests "the indispensability of environmental categoriesland, water, habitats, forests - in any literary, cultural or historical analysis 
of the conditions of migration" (148). The task of eco-criticism is therefore to investigate how different cultural understandings of nature and society, inflected by experiences of sexism, racism, and colonialism, have been used by writers at various historical moments (Huggan and Tiffin 15). Arguably, when inflected by capitalist discourses of tourism, environmentalism goes global. The question that presses is, then, can postcolonial critique and writing illustrate the links between ecology and tourism for transformative practices? Can it challenge the "deadly banality of globalization"?

The postcolonial critique of tourism sees the tourist as one of the most virulent perpetuators of neo-imperialism, turning "the exotic" natives into commodities and objects of curiosity. It is apparent that a substantial colonial legacy continues to exist with respect to global economies. This clearly has implications for the form and objectives of tourism development, which like colonialism deals with the exploitation of "places" for economic interests. Yet, postcolonial critique of the study of power relationships in tourism studies is a very recent development as claimed in the studies made by Huggan and Tiffin, and by Carrigan. Tourism is about creating a destination for consumption and then incorporating these places within the global capital system. Postcolonial analysis makes us realize that the subjugation and utilization of nature by the colonial powers is an experience that continues in postcolonial tourism as "eco-colonialism" and "eco-imperialism." Furthermore a critique of power relationships also brings us to interrogate issues that relate gender and tourism. It exposes the fact that the sexual imagery used in the marketing of certain postcolonial destinations perpetuates Orientalist representations of a sensual, sexually available, and subservient female oriental other. As a "producer" of destinations, tourism also comes to play a major role in the construction of place, especially in locations of multiple displacements where authenticity and identity are being constantly contested and renegotiated. However it must be noted that hegemony and resistance as binary categories in postcolonial theorization may not always be relevant. A postcolonial critique has to consider that both local and global processes of accommodation and collaboration inform these categories.

When discourse of tourism promotes the preservation of the "traditional" for tourist experience it replicates colonialist tropes of Otherness and categories of privilege and poverty. It is in this context that Carrigan's study of environment, tourism and the "postcolonial" is rich, complex and nuanced. In a project that involves the interrogation of tourism development, sustainability, and postcolonial writing, the author explores the humanizing potential of tourism.

Huggan and Tiffin draw our attention to the fact that development can be viewed ethically if the market is not just "a vehicle of self interest" but also an "instrument of social justice" (29). As Amartya Sen has argued, if development means removing sources of "unfreedom" (like poverty, illiteracy, 
social unrest) and enlarging human choices then it also means freedom to participate in the global market system. It would then be in the interest of postcolonialism to explore "humanizing the principles of economic productivity" and place sustainable local development within the global capitalist logic. Carrigan contends that even if postcolonial representations of tourism depict the destructive consequences of tourism's expanding development, they also contribute to the shaping of sustainable futures. He argues that creative writers operate in "anticipatory" and transformative ways, contributing to the future of the communities they depict by creating the space for sustainable practices. He adds that the ethical imperatives of fiction have relevance for world policy debates and should be taken as seriously as empirical research. This premise can only be transformative if such representations are considered to offer ways to negotiate tourist practices from within the neoliberal capitalist paradigm of the global industry. As Carrigan points out, this allows all the actors in tourism to be presented within the same system of "desire, exchange and circumscription," which gives them a greater potential to subvert tourism's logic (5).

Through a reading of literary works by several Caribbean and Pacific Ocean island writers, Carrigan interrogates the concept of sustainability and the development agenda by highlighting that destinations contain multiple and competing ideologies that reveal the complex workings of internal colonialism and environmental racism. Using the "postcolonial" as a paradigm in relation to tourism sustainability, Carrigan problematizes the concept of environmental vulnerability. This, particularly, in the case of islands is crucial to dislodging tourism development from binary relations between native poverty and dependency versus tourist privilege. His sophisticated reading of Naipaul, Kincaid, Walcott, and Hau'ofa's works, to name a few, show how these postcolonial texts play a crucial role in "critiquing exploitative practices, presenting imaginative strategies for industry negotiation and enhancing the cultural specificity of individual islands" (119).

\section{Literary Cosmopolitanism and the Question of Untranslatability}

As Boehmer and Morton as well as Ashcroft point out, postcolonial texts play a mediating role between imaginative and real-world concerns. By drawing individuals into a process of self-reflexivity, these texts help them perform the transition between fiction and real life that is vital to effect social change. For a long time, however, the "postcolonial" as a paradigm to describe "new writing" from ex-colonized cultures has been limited to anglophone productions. The bringing together of postcolonial theory and cultural productions in other languages is a recent phenomenon. Of course the globalization of commodities also includes the "perceived" free flow of texts across languages. How then are meanings managed when theory and cultural production traverse linguistic frontiers? Don't political and economic forces control translation and the circulation of translated texts? This brings me to the final section of 
the essay, which examines how the "postcolonial" operates as a paradigm in literary and academic cosmopolitanisms.

As shown in the previous sections on terror and tourism, postcolonialism in its "globalizing inflection" is commonly linked to migrant spaces where the colonial as the site of violence and the nation as a site of expectation have given way to spaces that inscribe transnational desires. Today for the most part, postcolonial writing is perceived as reflecting a hybrid, magic-realist world. Like postcolonial theory, postcolonial writing — enmeshed in the transnational processes of marketing and publishing - is seen to be complicit with the market-driven neo-capitalist economy. But as we have just observed, the "postcolonial" used synonymously with the transnational has been proven to be problematic, while on the other hand, its correlation with struggle, subversion, resistance to globalization and the processes of empire is capable of reducing it to a discourse of victimization. While such debates have been vibrant in anglophone postcolonial studies, the bringing together of francophone studies and the "postcolonial" is a very recent development. The volume, Transnational French Studies: Postcolonialism and Littérature-Monde, edited by Hargreaves, Forsdick, and Murphy, provides a summary of the main debates that centre around the relevance of the "postcolonial" in French studies with a special focus on a particular event that took place in Paris on 16 March 2007: the signing of the manifesto Pour une littérature-monde en français by forty-four francophone writers.

Arguably the seamlessly connected global economies have undermined the centrality of national structures. The French/metropolitan and francophone/ periphery binaries are no longer valid. Ideologically the manifesto seems to be offering a belated postcolonial resistance. However, the controversies it has raised show the complex inter-meshing of academic benefits, commercial ambitions, and ideological interests. As the volume reveals, the publication of the manifesto has found French departments in Anglo-American universities and French critics in France confronting the value and relevance of the "postcolonial" as theory and practice to understand "francophone" cultures. ${ }^{3}$ The Littérature-monde manifesto challenges the neo-colonial relationship between France and its former colonies via the structures of la Francophonie in order to recognize French as a world language that celebrates rhizome identities, hybridity, and cultural mobilities. In other words, the construction of a World Literature in French is based on the recognition of the "transnational" nature of French as opposed to one constructed within the colonial framework of centre and periphery geographies. However, as several contributors to the volume Transnational French Studies: Postcolonialism and Littérature-Monde point out, this "transnational turn" could end up being a mere utopian ambition, one that does not wish to engage with political and historical legacies of colonial writing and representations. 
Furthermore, while the authors (both diasporic and metropolitan) of the manifesto, targeting the French literary and publishing institutions in a manner of belated postcolonial resistance, announce the end of la Francophonie as a colonial institution, the volume draws our attention to the fact that the manifesto reflects the contradictions of "transnationalizing" discourses that ignore the complexities of small but effective pockets of resistance. As Thomas Spear affirms in his essay, by ignoring the presence of smaller French publishers whose policies have been more inclusive, and places like Lebanon, Algeria, and Quebec where a substantial number of French language books are published (especially Quebec where more books per capita are published than in France), the manifesto reaffirms metropolitan hegemony instead of subverting it (172). ${ }^{4}$ By insisting on the transnationalizing potential of their writing, the authors of the manifesto may be falling into the trap of what Deborah Jenson calls "decadent cosmopolitanism," thereby uncovering the shortcomings of the "postcolonial" as a hybridizing inflection. "Littérature-monde as a willed identity implies that what I call the decadent cosmopolitanism of the new millennium legitimately edges voice and aesthetics away from identity politics, especially those derived from the particular modern monumentality of colonial triangular trade and towards a universalism born out of migrant trajectories of globalization" (21).

Jenson's critique is spot on. It shows how the celebratory tone of the manifesto actually masks the pitfalls that a banalizing globalization provokes. When the concept of "World Literatures" was first used by Salman Rushdie in the 1980s to refer to literatures in English that were being produced by non-English writers of different racial and geographical origins, it was very liberating because it de-centred the English language and drew our attention to the world of "translated" men. This is Rushdie's term and is used by the authors of the manifesto to refer to their own ambitions (298). But as Deborah Jenson points out, the victory of the "translated man" can be bitter and meaningless if unengaged and unconscious of his own transnational hegemonic position (32). Echoing Jensen, Emily Apter in her Afterword to Transnational French Studies: Postcolonialism and Littérature-Monde argues that the conflation of "postcolonial," "world," and "transnational" devalues the untranslatability and non-translation for the politics of cultural relations and critiques the World literature in French project as a historical cosmopolitan project projecting a "denationalized planetary screen" where the "shifting definition of world from language to language and context to context" is not considered (288). "Untranslatability" is an unpopular word today, yet as Apter notes in her article "Philosophical Translation and Untranslatability: Translation as a Critical Pedagogy.", the focus on the untranslatable is important if we wish to move away from a "soft international diplomacy model" and from the tendency to seek similarity and erase disagreement in order to avoid confrontation with "insecurable knowledge" (61). The othering of indigenous 
voices under colonialism was felt in the policies of apartheid and in other forms of institutionalized separation that affected all fields of production. Today, it would seem that the over emphasis on mutuality may produce another form of exclusion that originates in the desire for similarity. In other words, categories like "cosmopolitan," "translated man," or "migrant" that inflect the hybridizing tendency of the "postcolonial" might occlude the perspectives of those who cannot migrate, translate, or cosmopolitanize themselves. Recognizing untranslatability not merely as a linguistic phenomenon but as a philosophical construct entails that resistance should be recognized before the intermingling of resistance and reconciliation is endorsed. In this sense, the validity of "postcolonial" in defining World literature in French remains relevant as it conserves its "resistance inflection," a significant factor both from the point of view of cultural production and in terms of its reception by academics and lay readers.

\section{Conclusion}

Besides interrogating phenomena like terror, tourism, and cosmopolitanism as processes bringing together Western and non-Western cultures in unequal power relationships, can "postcolonial" as a category of resistance be used to look at hegemonies within modern societies of the First World? In The Empire Within: Postcolonial Thought and Political Activism in Sixties Montreal, Sean Mills shows how in the 1960s Québécois activists of diverse backgrounds perceived themselves as part of a broader world movement of anti-imperialist resistance. Mills' argument is that the radicalism of the 1960s that gave birth to the idea of Quebec sovereignty must be read from the wider angle of international movements for independence, racial equality, and women's rights. Some may consider such a "postcolonial" paradigm a refreshing perspective because it places the narrative of Quebec separatism outside of Canadian history, culture, and politics. However, by ignoring "local" specificities relating to Canada's history of British "ethnicity" (Igartua) and the complex question of language rights, neither of which are factored in postcolonial theoretical considerations, Mills may, in fact, be throwing the baby out with the bath water. The "postcolonial" as critical lens facilitates the understanding of some of key issues that we confront every day in our geopolitical present, but its success lies not in its "finiteness" but in its transformative and self-reflexive potential to review its theoretical and political limitations. When "postcolonial" is integrated creatively into other paradigms like the "cosmopolitan," the "transnational," and the "global," it not only shows up their inadequacies, but also its own constraints, thus providing a more nuanced explanation of contemporary society. As these brief reflections on some recent postcolonial studies have shown, postcolonial critics, for the most part, are willing to engage with some crucial philosophical (sublime), ethical (untranslatability), and empirical (environmental sustainability) questions. Mbembe's suggestion that 
it is in the engagement with the non-political that "postcolonial" has relevance today, ${ }^{5}$ seems to have found resonance with several postcolonial scholars.

\section{Notes}

1. Young - distinguishing between postcolonialism, postcolonial, and postcoloniality - draws our attention to the fact that the postcolonial is a dialectical concept marking the historical fact of decolonization. It is also a set of economic, cultural, and political conditions that determine the operation of the postcolonial, and it refers to a theoretical position committed towards political ideals of transnational social justice. In this essay, the category of the "postcolonial" refers to all three aspects outlined by Young (57-58).

2. "We believe that the dynamics structuring the world order after 2003 are much the same as those structuring it before 2003 - and, for that matter, those structuring it before 2001, or 1989, or even 1973, 1968, 1956, or 1945. What we are proposing is that, 'after Iraq', postcolonial studies must change not because the world has changed but because 'Iraq' shows that, in quite substantial ways, it has not changed" (Gopal and Lazarus).

3. As Forsdick notes in "Challenging the Monolingual, Subverting the Monocultural," affirming the "Francophone postcolonial" as a relevant academic field of enquiry is a response to the monolingual dimension of postcolonial criticism and the metropolitan bias of French studies.

4. Ironically, the volume, overall, fails to address this particular issue: the relative invisibility of Francophone Canadian (Quebec and "hors Québec") literary institutions in the discussions contained here underscores the ambiguities of the transnational, global, and postcolonial as relevant categories in the context of "Francophone" institutions.

5. "How can we account for the contemporary ways in which the political, under the guise of war, of resistance or of the fight against terror, makes the murder of the enemy its primary and absolute objective? Such a way of defining the issues raises a number of empirical and philosophical questions postcolonial theory has to address if it is still to be intellectually relevant" comments Achille Mbembe in an interview with Christian Höller, editor of Springerin Magazine (http://www.springerin.at/dyn/heft.php?id=32\&pos=0\&textid=0\&lang=en).

\section{Works Cited}

Apter, Emily. "Philosophical Translation and Untranslatability: Translation as a Critical Pedagogy." Profession (2010): 50-63. "The Afterword: The 'World' in World Literature," in Hargreaves, Alec G., Charles Forsdick, and David Murphy (eds.). Transnational French Studies: Postcolonialism and LittératureMonde. Liverpool: Liverpool University Press, 2010: 287-295.

Ashcroft, Bill. "Alternate Modernities: Globalisation and the Postcolonial." ARIEL: A Review of International English Literature 40.3 (2009): 81-105.

Berleant, Arnold. "Art, Terrorism and the Negative Sublime." Contemporary Aesthetics 7 (2009). http://www.contempaesthetics.org/newvolume/pages/ article.php?articleID=56. 1 August 2011.

Boehmer, Elleke, and Stephen Morton (eds.). Terror and the Postcolonial: A Concise Companion. Malden, MA: Wiley-Blackwell, 2010. 
Boehmer, Elleke, and Stephen Morton. "Introduction: Terror and the Postcolonial," in Boehmer, Elleke, and Stephen Morton (eds.). Terror and the Postcolonial: A Concise Companion. Malden, MA: Wiley-Blackwell, 2010 : 1-24.

Boehmer, Elleke, "Postcolonial Writing and Terror," in Boehmer, Elleke, and Stephen Morton (eds.). Terror and the Postcolonial: A Concise Companion. Malden, MA: Wiley-Blackwell, 2010: 141-150.

Carrigan, Anthony. Postcolonial Tourism: Literature, Culture, and Environment. New York: Routledge, 2011.

Dirlik, Arif. "The Postcolonial Aura: Third World Criticism in the Age of Global Capitalism." Critical Inquiry 20 (1994): 328-56.

Forsdick, Charles. "Challenging the Monolingual, Subverting the Monocultural: The Strategic Purposes of Francophone Postcolonial Studies." Francophone Postcolonial Studies 1.1 (2003): 33-41.

Gikandi, Simon. Maps of Englishness: Writing Identity in the Culture of Colonialism. New York: Columbia UP, 1996.

Gopal, Priyamvada, and Neil Lazarus. Editorial: “After Iraq: Reframing Postcolonial Studies." New Formations: A Journal of Culture/Theory/Politics 59 (2006). http://www.lwbooks.co.uk/journals/newformations/archive/newformations59. html. 1 August 2011.

Hargreaves, Alec G., Charles Forsdick, and David Murphy (eds.). Transnational French Studies: Postcolonialism and Littérature-Monde. Liverpool: Liverpool University Press, 2010.

Höller, Christian. "An Interview with the Post-Colonialism Theoretician Achille Mbembe." Springerin 3.2. http://www.springerin.at/dyn/heft.php?id=32\&pos=0 \&textid=0\&lang=en. 1 August 2011.

Huggan, Graham, and Helen Tiffin. Postcolonial Eco-criticism. London: Routledge, 2010.

Igartua, José E. The Other Quiet Revolution: National Identities in English Canada 1945-71. Vancouver: University of British Columbia Press, 2007.

Jenson, Deborah. "Francophone World Literature (Littérature-monde), Cosmopolitanism and Decadence: 'Citizen of the world' without the Citizen?" in Hargreaves, Alec G., Charles Forsdick, and David Murphy (eds.). Transnational French Studies: Postcolonialism and Littérature-Monde. Liverpool: Liverpool University Press, 2010: 15-35.

Kavoori, Anandam, "International Communication after Terrorism: Toward a Postcolonial Dialectic," in Kavoori, Anandam, and P. Todd Fraley (eds.). Media, Terrorism, and Theory: A Reader. Maryland: Rowman \& Littlefield, 2006: $179-198$

McClintock, Anne. "The Angel of Progress: Pitfalls of the Term 'PostColonialism." Social Text, 31/32 (1992): 84-98.

Mbembe, Achille. "The Colony: Its Guilty Secret and Its Accursed Share", in Boehmer, Elleke, and Stephen Morton (eds.). Terror and the Postcolonial: A Concise Companion. Malden, MA: Wiley-Blackwell, 2010: 27-54. On the Postcolony. Berkeley: University of California Press, 2001.

Mukherjee, Pablo. "Surfing the Second Waves, Amitav Ghosh's Tide Country," New Formations: A Journal of Culture/Theory/Politics, 59 (2006): 144-57.

Mills, Sean. The Empire Within: Postcolonial Thought and Political Activism in Sixties Montreal. Montreal: McGill-Queen's University Press, 2010. 
Sen, Amartya. Development as Freedom. Oxford: Oxford University Press. 1999. Shohat, Ella. "Notes on the 'Post-Colonial'," Social Text, 31-32 (1992): 99-113.

Slemon, Stephen. "Unsettling the Empire: Resistance Theory for the Second World." World Literature Written in English 30.2 (1990): 30-41.

Spear, Thomas. "(R)evolutions”, in Hargreaves, Alec G., Charles Forsdick, and David Murphy(eds). Transnational French Studies: Postcolonialism and Littérature-Monde. Liverpool: Liverpool University Press, 2010: 164-177.

Yaeger, Patricia. Editor's Column: "The End of Postcolonial Theory?" PMLA 122.3 (2007): 633-51.

Young, Robert J. C. Postcolonialism: An Historical Introduction. London: Black \& Wiley, 2001. Terror Effects," in Boehmer, Elleke, and Stephen Morton (eds). Terror and the Postcolonial: A Concise Companion. Malden, MA: WileyBlackwell, 2010: 307-328. 